\title{
Improving Quality Attributes of Litchi (Litchi chinensis Sonn.) cv. Rose Scented by Preharvest Foliar Applications
}

\author{
Ankit Dongariyal", Navin Singh, K.K. Misra and Avishek Roy
}

College of Agriculture, Department of Horticulture, GBPUA\&T, Pantnagar-263145, India

*Corresponding author

\section{A B S T R A C T}

\section{Keywords}

Fruit quality, Ethrel, Di-potassium phosphate, Monopotassium phosphate, Potassium nitrate, Thiourea

\section{Article Info}

Accepted:

12 December 2018

Available Online:

10 January 2019
The present investigation was carried out at Horticultural Research Centre, Patharchatta, GBPUA\&T, Pantnagar during September, 2015 to June, 2016. The experiment was conducted to study the effect of ethrel, potassic chemicals i.e. di-potassium hydrogenortho-phosphate $\left(\mathrm{K}_{2} \mathrm{HPO}_{4}\right)$, potassium di-hydrogen orthophosphate $\left(\mathrm{KH}_{2} \mathrm{PO}_{4}\right)$, potassium nitrate $\left(\mathrm{KNO}_{3}\right)$ and thiourea on quality attributes of litchi cv. Rose Scented. The treatments included $\mathrm{T}_{1}$-ethrel (400 ppm), $\mathrm{T}_{2}-\mathrm{KNO}_{3}(1 \%), \mathrm{T}_{3}-\mathrm{K}_{2} \mathrm{HPO}_{4}(1 \%), \mathrm{T}_{4}-\mathrm{KH}_{2} \mathrm{PO}_{4}(1 \%), \mathrm{T}_{5^{-}}$ thiourea (1\%), $\mathrm{T}_{6}-\mathrm{K}_{2} \mathrm{HPO}_{4}(2 \%), \mathrm{T}_{7}-\mathrm{KH}_{2} \mathrm{PO}_{4}(2 \%), \mathrm{T}_{8}-\mathrm{K}_{2} \mathrm{HPO}_{4}(1 \%)+\mathrm{KNO}_{3}(1 \%), \mathrm{T}_{9^{-}}$ $\mathrm{KH}_{2} \mathrm{PO}_{4}(1 \%)+\mathrm{KNO}_{3}(1 \%), \mathrm{T}_{10}-\mathrm{K}_{2} \mathrm{HPO}_{4}(1 \%)+$ thiourea $(0.5 \%), \mathrm{T}_{11}-\mathrm{KH}_{2} \mathrm{PO}_{4}(1 \%)+$ thiourea $(0.5 \%), \mathrm{T}_{12}-\mathrm{KNO}_{3}(1 \%)+$ thiourea $(0.5 \%)$ and $\mathrm{T}_{13}$ as control (water spray). The experiment was laid out in randomized block design with 13 treatments and 3 replications. Three spray of each treatment was applied during last week of September to November (at 20 days interval). The results indicated that all the treatments significantly improved quality parameters of litchi fruits as compared to control. Maximum TSS $\left(19.22^{\circ}\right.$ Brix), TSS/acidity ratio (61.44), reducing sugar (11.87\%) total sugar (13.34\%) and minimum acidity $(0.31 \%)$ were reported with the application of ethrel @ 400 ppm whereas maximum ascorbic acid $\left(33.17 \mathrm{mg} / 100 \mathrm{~g}\right.$ pulp) was observed in $\mathrm{T}_{8}\left(\mathrm{~K}_{2} \mathrm{HPO}_{4} @ 1 \%+\right.$ $\mathrm{KNO}_{3} @ 1 \%$ ) treatment.

\section{Introduction}

The litchi (Litchi chinensis Sonn.) is most important subtropical fruit of the Sapindaceae family grown throughout the world. It is believed to have originated in Southern China and Northern Vietnam region and became widely distributed in the Subtropics (Menzal and Simpson, 1986). In India it reached via Burma by the end of $17^{\text {th }}$ century. India is second largest litchi producer in the world next to China. The annual production of litchi in India accounts to 583 thousand metric tonnes from an area of 85 thousand hectare with an average productivity of 6.3 metric tonnes/ha (Anonymous, 2017). In India major litchi growing states are Bihar, West Bengal, Uttar Pradesh, Uttarakhand, Punjab, Arunanchal Pradesh, Karnataka and Tripura. In Uttarakhand, annual production of litchi accounts for 19.16 thousand metric tonnes from an area of 9.49 thousand hectares. The major litchi producing areas in Uttarakhand are Dehradun, Haridwar, Nainital, Udham Singh Nagar districts with minor production in 
Pithoragarh and Pauri Garhwal districts. It has a vast potential of cultivation in the entire Tarai belt of Uttarakhand. The mature litchi fruits are high in sugar content which varies from 6.74 to 18.86 per cent in Indian cultivars (Singh and Singh, 1964). Besides sugar, litchi is an excellent source of vitamin C (40 $\mathrm{mg} / 100 \mathrm{~g}$ ) and contains significant amount of protein $(0.8-0.9 \%)$, fat $(0.3 \%)$, pectin $(0.43 \%)$ and mineral content especially calcium, phosphorus and iron (Pandey and Sharma, 1998). Besides being non-climacteric, Litchi fruits are highly perishable and their fruit quality characteristics are influenced by many biotic and abiotic factors. Therefore, any efforts that could be done to maintain the litchi fruits with high quality characteristics such as fruit size, weight, firmness, colour intensity and uniformity after harvest, and during marketing would be very important for the litchi growers in order to obtain higher monetary return. Foliar application of plant nutrients is helpful in satisfying plant requirements and can be highly efficient when nutrient uptake via the root system is limited. Potassium is required for the production and transport of plant sugars that increase the weight of fruit. As an activator of many enzymes, $K$ plays a vital role in photosynthesis, protein synthesis and acts as a major counterion in establishment of transmembrane $\mathrm{pH}$ gradient during ATP synthesis. Phloem loading, transport rate and unloading of sucrose which are key processes for optimum yield with quality fruits are enhanced by optimum level of plant K. During reproductive development competition for photoassimilates between developing fruits and vegetative organs may inhibit root growth and nutrient uptake, including K. Therefore, foliar spray of potassium is very effective, especially in the later stages of the growth. Ethrel have a great influence on fruit maturation, ripening and quality of litchi fruits. Sadhu and Chattopadhyay (1989) reported promotion of fruit ripening and colouration in litchi by improving the anthocyanin levels in the peel and increased TSS, sugars, ascorbic acid and decreased acidity in pulp by foliar application of Ethephon@2500 ppm while ethrel @ 800 $\mathrm{mg} / \mathrm{l}$ at colour break was responsible for highest anthocyanin levels in litchi cv Nuomici (Wang et al., 2007). Keeping in view the above factors under consideration, the present experiment was conducted to study the effect of potassic compounds, ethrel and thiourea on chemical attributes of litchi fruits grown under the Tarai region of Uttarakhand.

\section{Materials and Methods}

The experiment was carried out at Horticultural Research Centre, Patharchatta, Pantnagar. Fifteen years old litchi trees of cv. Rose Scented planted at $10 \mathrm{~m}$ distance in square system were selected for the experiment. All the selected trees were of uniform vigour and size. The experiment comprised of 13 treatments allocated in Randomised Block Design with three replications. One tree served as a unit of treatment in each replication. The treatments comprised of different concentration of potassic chemicals i.e. di-potassium hydrogenortho-phosphate $\left(\mathrm{K}_{2} \mathrm{HPO}_{4}\right)$, potassium dihydrogen orthophosphate $\left(\mathrm{KH}_{2} \mathrm{PO}_{4}\right)$, potassium nitrate $\left(\mathrm{KNO}_{3}\right)$, ethrel and thiourea along with some combinations viz., $\mathrm{T}_{1}$-ethrel (400 ppm), $\mathrm{T}_{2}-\mathrm{KNO}_{3}(1 \%), \mathrm{T}_{3}-\mathrm{K}_{2} \mathrm{HPO}_{4}(1 \%)$, $\mathrm{T}_{4}-\mathrm{KH}_{2} \mathrm{PO}_{4} \quad(1 \%), \quad \mathrm{T}_{5}$-thiourea $(1 \%), \quad \mathrm{T}_{6^{-}}$ $\mathrm{K}_{2} \mathrm{HPO}_{4}(2 \%), \mathrm{T}_{7}-\mathrm{KH}_{2} \mathrm{PO}_{4}(2 \%), \mathrm{T}_{8}-\mathrm{K}_{2} \mathrm{HPO}_{4}$ $(1 \%)+\mathrm{KNO}_{3}(1 \%), \mathrm{T}_{9}-\mathrm{KH}_{2} \mathrm{PO}_{4}(1 \%)+\mathrm{KNO}_{3}$ $(1 \%), \mathrm{T}_{10}-\mathrm{K}_{2} \mathrm{HPO}_{4}(1 \%)+$ Thiourea $(0.5 \%)$, $\mathrm{T}_{11}-\mathrm{KH}_{2} \mathrm{PO}_{4}(1 \%)+$ thiourea $(0.5 \%), \mathrm{T}_{12^{-}}$ $\mathrm{KNO}_{3}(1 \%)+$ thiourea $(0.5 \%)$ and $\mathrm{T}_{13}$ as control (water spray). Foliar application of the chemicals was done using back-held knapsack sprayer. After each treatment, the pump was washed thoroughly. A teaspoon of commercial washing powder was added as a wetting agent 
for effective result and for improvement in absorption. All foliar spraying was carried out early in the morning. Three spray of each chemical was applied during last week of September to November (at 20 days interval). The observations on Total soluble solids ( ${ }^{0}$ Brix) were recorded at room temperature using hand refractometer. Ten fruits from each replication were taken for the average value. Total acidity of the litchi fruits was calculated by titrating the fruit juice against standard $\mathrm{N} / 10 \mathrm{NaOH}$. TSS/ acidity ratio was computed by dividing the TSS values of the sample with its corresponding acidity values in each replication of all treatments. Ascorbic acid content of the fruits was determined by titrating the pulp extract by 2,6dichlorophenol indophenol dye. The Total sugar, reducing and non-reducing sugars were estimated using Fehling solution. The data were subjected to statistical analysis as per the method of Snedecor and Cochran (1967). Least significant of difference at $5 \%$ level was used for finding the significance of differences if any, among the treatment means.

\section{Results and Discussion}

The results reveal that maximum TSS content (19.22) was observed in treatment $\mathrm{T}_{1}$ (ethrel @ 400 ppm) while the minimum TSS content (18.18) was recorded in $\mathrm{T}_{13}$ (control). Increase in TSS content is mostly due to the increase in sugar content which depends mostly upon conversion of starch on hydrolysis. Crane (1956) reported that auxin content caused mobilization of soluble carbohydrates into fruits. In the present experiment ethrel probably promoted such mobilisation in the fruits consequently resulting in increased soluble solids. The present findings are in close conformity with Kacha et al., (2012) in phalsa, Abbas et al.,
(1994) in ber and Ventateshan and Tamilmani (2013) in mango. In all the treatments acidity percent significantly ranged between 0.31 to 0.38 percent. The minimum acidity $(0.31 \%)$ was recorded in $\mathrm{T}_{1}$ (ethrel @ $400 \mathrm{ppm}$ ) whereas maximum acidity $(0.38 \%)$ was observed in $\mathrm{T}_{13}$ (control). The decrease in acidity may be due to the inverse correlation between soluble solids and acidity. Ethrel application increases the rate of ethylene production due to which fructose, glucose and sucrose contents in fruit increase significantly which leads to the increase in soluble solids and decrease in titratable acidity of fruits (Park, 1996). According to the Ruffner et al., (1975) the acids under the influence of chemicals are either been fastly converted into sugar and reducing sugar by the reaction involving the reversal of glycolytic path way or might be used in respiration or both. There was a significant effect of different treatments on TSS: acidity ratio as compared to control. Maximum TSS/acidity ratio (61.44) was recorded in treatment $\mathrm{T}_{1}$ (ethrel @ 400 ppm). On the other hand minimum TSS: acidity ratio (47.43) was observed in $\mathrm{T}_{13}$ (control) treatment. All the treatments significantly increased the sugar content as compared to control. The treatment $\mathrm{T}_{1}$ (ethrel @ 400 ppm) resulted maximum reducing sugar content (11.87\%) whereas minimum (10.59\%) was recorded in $T_{13}$ (control). The treatment $T_{1}$ also recorded maximum total sugar content (13.34). Sucrose, fructose and glucose are the main sugars present in the aril of litchi fruit. It seems ethrel might have caused an increase in hydrolytic activities in the fruits which resulted in increased sugar content (Wang and Zhang, 2000). Hydrolytic activities can give rise to increase in sugar not only from starch but also from fat (Beevers, 1961). Similar increase in sugars by ethrel was reported by Bal et al., (1992) in ber and Farag et al., (2012) in apricot (Table 1). 
Table.1 Effect of different treatments on quality attributes of litchi cv. Rose Scented

\begin{tabular}{|c|c|c|c|c|c|c|c|}
\hline Treatments & $\begin{array}{c}\text { TSS } \\
\left({ }^{0} \text { Brix }\right)\end{array}$ & $\begin{array}{c}\text { Acidity } \\
(\%)\end{array}$ & $\begin{array}{c}\text { TSS/ } \\
\text { acidity } \\
\text { ratio }\end{array}$ & $\begin{array}{c}\text { Reducing } \\
\text { Sugar } \\
(\%)\end{array}$ & $\begin{array}{c}\text { Total } \\
\text { sugar } \\
(\%)\end{array}$ & $\begin{array}{c}\text { Non } \\
\text { reducing } \\
\text { sugar } \\
(\%)\end{array}$ & $\begin{array}{l}\text { Ascorbic } \\
\text { acid (\%) }\end{array}$ \\
\hline Ethrel (400ppm) & 19.22 & 0.31 & 61.44 & 11.87 & 13.34 & 1.47 & 31.08 \\
\hline $\mathrm{KNO}_{3}(1 \%)$ & 18.80 & 0.33 & 55.91 & 11.69 & 13.11 & 1.42 & 29.41 \\
\hline $\mathrm{K}_{2} \mathrm{HPO}_{4}(1 \%)$ & 18.31 & 0.35 & 51.85 & 11.39 & 12.69 & 1.30 & 28.25 \\
\hline $\mathrm{KH}_{2} \mathrm{PO}_{4}(1 \%)$ & 18.36 & 0.34 & 53.61 & 11.55 & 12.81 & 1.26 & 31.35 \\
\hline Thiourea $(0.5 \%)$ & 18.27 & 0.37 & 49.40 & 11.14 & 12.45 & 1.31 & 31.03 \\
\hline $\mathrm{K}_{2} \mathrm{HPO}_{4}(2 \%)$ & 18.69 & 0.35 & 52.96 & 11.15 & 12.52 & 1.37 & 33.14 \\
\hline $\mathrm{KH}_{2} \mathrm{PO}_{4}(2 \%)$ & 18.45 & 0.36 & 50.80 & 11.00 & 12.34 & 1.34 & 32.04 \\
\hline $\mathrm{K}_{2} \mathrm{HPO}_{4}(1 \%)+\mathrm{KNO}_{3}(1 \%)$ & 18.68 & 0.34 & 54.49 & 10.86 & 12.32 & 1.45 & 33.17 \\
\hline $\mathrm{KH}_{2} \mathrm{PO}_{4}(1 \%)+\mathrm{KNO}_{3}(1 \%)$ & 18.75 & 0.33 & 55.77 & 11.50 & 12.69 & 1.18 & 29.59 \\
\hline $\begin{array}{c}\mathrm{K}_{2} \mathrm{HPO}_{4}(1 \%)+\text { Thiourea } \\
(\mathbf{0 . 5 \% )}\end{array}$ & 18.28 & 0.36 & 50.81 & 11.25 & 12.36 & 1.10 & 28.68 \\
\hline $\begin{array}{l}\mathrm{KH}_{2} \mathrm{PO}_{4}(1 \%)+\text { Thiourea } \\
(0.5 \%)\end{array}$ & 18.34 & 0.37 & 49.13 & 11.59 & 12.71 & 1.12 & 28.69 \\
\hline $\begin{array}{c}\mathrm{KNO}_{3}(\mathbf{1 \%})+\text { Thiourea } \\
(\mathbf{0 . 5 \% )}\end{array}$ & 18.40 & 0.35 & 51.63 & 11.14 & 12.20 & 1.05 & 28.46 \\
\hline Control (water spray) & 18.18 & 0.38 & 47.43 & 10.59 & 12.07 & 1.47 & 27.35 \\
\hline S. $\mathbf{E m} \pm$ & 0.042 & 0.008 & 1.243 & 0.028 & 0.042 & 0.048 & 1.020 \\
\hline C D at $5 \%$ & 0.124 & 0.023 & 3.628 & 0.082 & 0.124 & NS & 2.978 \\
\hline
\end{tabular}

The non reducing sugar percent in all the treatments was found non significant. Maximum ascorbic acid content (33.17 $\mathrm{mg} / 100 \mathrm{~g}$ pulp) was found in $\mathrm{T}_{8}\left(\mathrm{~K}_{2} \mathrm{HPO}_{4} @\right.$ $\left.1 \%+\mathrm{KNO}_{3} @ 1 \%\right)$. On the other hand minimum ascorbic acid content (27.35 $\mathrm{mg} / 100 \mathrm{~g}$ pulp) was found in treatment $\mathrm{T}_{13}$ (control).The increase in ascorbic acid content may be due to the catalytic influence of the growth.

\section{References}

Anonymous (2017). NHB, Gurgaon, India. Abbas, M.K., Niami, J.H. and Sereh, E.A. 1994. The effect of ethephon on ripening of fruits of jujube. Journal of Horticultural Science, 401: 465-466.

Bal, J.S., Kahlon, P.S., Jawanda, J.S. and Sandhu, S.S. 1992. Effect of pre-harvest spray of growth regulators at turning stage on the maturity of ber fruits (Zizyphus mauritiana Lamk.). Acta Horticulturae, 321: 318-325.

Beevers, H. 1961. Metabolic production of sucrose from fat. Nature, 191: 433-436.

Crane, J.C. 1956. The comparative effectiveness of several growth regulators for controlling preharvest drop, increasing size, hastening maturity of Stewar apricots. American Society of Horticultural Sciences, 57:153-159.

Farag, K.M., Haikal, A.M. and Attia, S.M. 2012. Effect of some pre harvest treatments on Apricot Fruits. Australian Journal of Basic and Applied Sciences, 6(7): 518531.

Kacha, H.L., Viradia, R.R., Leua, H.N., Jat, G. and Tank, A.K. 2012. Effect of NAA, $\mathrm{GA}_{3}$ and ethrel on yield and quality of phalsa (Grewia asiatica L.) under SouthSaurashtra condition. The Asian Journal of Horticulture, 7(2): 242-245. 
Menzel, C.M. and Simpson, D.R. 1986. The lychee nutrition story. Proc.Second Nat. Lychee, Seminar, Australia. pp 55-70.

Menzel, C.M., Chapman, K.R., Paxton, B.F. and Simpson, D.R. 1986. The litchi nutrition. Australian Journal of Experimental Agriculture, 26: 261-265.

Pandey, R.S. and Sharma, H.C. 1998. The Litchi. Indian Council of Agricultural Research, New Delhi. 68p.

Park, Y.S. 1996. The shelf life of kiwifruit in room temperature and cold storage following controlled atmosphere storage. Korean Society of Horticultural Science, 37: $58-63$.

Rangana, S. 1986. Handbook of Analysis and Quality Control for Fruit and Vegetable Products. II edn. Tata McGraw-Hill Publ. Co., New Delhi.

Ruffner, H.P., Hoblet, W. and Rast, D. 1975. Gluconeogenesis in the ripening berries of Vitis vinifera. Vitis, 13: 319- 328.

Sadhu, M.K. and Chattopadhyay, G. 1989. Effect of post-harvest fruit dip in ethephon on the ripening of litchi fruits. Journal of Horticultural Science, 64(2): 239-242.

Seibert, E., Iguassu, C., Barradas, N. and Araujo, P.J., Bender, R.J. 2000. Effect of ethephon on fruit quality of pear cv. Packham's Triumph. Acta Horticulturae, 3(1): 1678-3921.

Shanmugavelu, K.G., Rao, V.N.M. and Shrinivasan, C. 1973. Studies on the effect of certain plant regulators and boron on papaya. South Indian Journal of Horticulture, 21:10-26.

Shaybany, B. and Sharifi, H. 2015. Effect of preharvest applications of ethephon on leaf abscission, fruit drop and constituents of fruit juice in pomegranate. Journal of horticultural science, 48(3): 293-296.

Singh, A., Abidi, A.B., Srivastava, S. and Singh, L.S. 1987. Correlations among physical and biochemical traits in litchi (Litchi chinensis Sonn.). Narendra Dev Journal of Agricultural Research, 2(2): 160-163.

Singh, L.B. and Singh, U.P. 1964. The Litchi, Superitendant Printing and Stationary, Uttar Pradesh, pp. 19-24.

Smith, E.R. and Whiting, M.A. 2010. Effect of ethephon on sweet cherry pedicel-fruit retention force and quality is cultivar dependent. Plant Growth Regulators, 60: 213-223.

Snedecor, G.W. and Cochran, G.W. 1967. Statistical Methods, $6^{\text {th }}$ Ed. Oxford and I.B.H., New Delhi.

Venkatesan, T. and Tamilmani, C. 2013. Effect of ethrel on the physiochemical changes of off-season fruits of mango (Mangifera indica L. var. Neelum) during ripening. International Journal of Agricultural and Food Science, 3(4): 171-175.

Wang, Y.Z. and Zhang, D. 2000. Regulating effects of ethylene on carbohydrate metobolism in 'Starkrimson' apple fruit during the ripening period. Acta Horticulturae, 27(6): 391-395.

Wang, H., Huang, H. and Huang, X. 2007. Differential effects of abscissic acid and ethylene on the fruit maturation of Litchi chinensis Sonn. Plant Growth Regul., 52: 189-198.

Zhang, L., Li, S., Liu, X. and Song, C. 2011. Effects of ethephon on physicochemical and quality properties of kiwifruit during ripening. Postharvest Biology and Technology, 65: 69-70.

\section{How to cite this article:}

Ankit Dongariyal, Navin Singh, K.K. Misra and Avishek Roy. 2019. Improving Quality Attributes of Litchi (Litchi chinensis Sonn.) cv. Rose Scented by Preharvest Foliar Applications. Int.J.Curr.Microbiol.App.Sci. 8(01): 1475-1479. doi: https://doi.org/10.20546/ijcmas.2019.801.157 